\title{
Protective efficacy of vaccination with NcMIC3 and NcMIC8 against Neospora caninum infection in mice
}

\author{
Taotao ZHANG, Xiao ZHANG, Qun LIU, Jianhai XU, Jing LIU (凶) \\ National Animal Protozoa Laboratory, College of Veterinary Medicine, China Agricultural University, Beijing 100193, China
}

\begin{abstract}
Microneme proteins (MICs) are important for Apicomplexan parasite invasion due to their adhesion to host cells. Several studies have indicated that Neospora caninum MIC3 and MIC8 are important adhesion factors and potential vaccine candidates against neosporosis. In this study, we evaluated the protective efficacy of recombinant proteins and DNA vaccines of NcMIC3 and $\mathrm{NcMIC} 8$. BALB/c mice were immunized with $\mathrm{rNcMIC} 3$, rNcMIC8, pcDNA3.1-NcMIC3 and pcDNA3.1-NcMIC8 respectively, and challenged with $N$. caninum tachyzoites. The immune responses were evaluated through cytokine, antibody measurements and the parasite burden in the mice brain tissues. Serological analysis showed that recombinant protein vaccines induced higher levels of immunoglobulin $\mathrm{G}(\mathrm{IgG})$ than other groups. The percentage of IgG1 and IgG2a in the recombinant protein groups was higher than the other groups, and with a predominance of IgG1 over IgG2a, suggesting that recombinant protein vaccines elicited a Th2-type immune response, while DNA vaccines mainly produce a Th1-type immune response. In addition, mice immunized with $\mathrm{rNcMIC} 3$ and $\mathrm{rNcMIC} 8$ a had lower parasite burden in brain tissue compared with the other groups. These results demonstrate that rNcMIC3 and $\mathrm{rNcMIC} 8$ could induce humoral and Th2-type immune response, leading to a considerable level of resistance against neosporosis.
\end{abstract}

Keywords NcMIC3, NcMIC8, Neospora caninum, vaccination

\section{Introduction}

Neospora caninum is an obligate intracellular parasite belonging to the phylum Apicomplexa ${ }^{[1]}$. In 1988, it was originally isolated from the brain tissue of a dog with hind limb paralysis and was identified as a Toxoplasma gondii-

Received November 26, 2018; accepted January 16, 2019

Correspondence: liujingvet@cau.edu.cn like organism ${ }^{[2]}$. It is now considered a distinct species that causes neosporosis. Neosporosis is a major cause of infectious abortion and congenital disease in cattle, persisting in cattle herds via transplacental transmission ${ }^{[3]}$. Therefore, neosporosis causes huge economic losses for the global livestock industry ${ }^{[4]}$. To date, there are no drugs licensed for the control of neosporosis in cattle ${ }^{[5]}$. Various vaccines for neosporosis have been explored, including live, killed or inactivated parasite vaccines ${ }^{[6,7]}$. However, there are safety problems and higher production costs with live vaccines. A vaccine based on whole killed tachyzoites (Bovilis-Neoguard, Intervet, Merck Animal Health, Madison, NJ, USA) was commercialized, however, it induced only partial protection against abortion and did not prevent vertical transmission ${ }^{[8]}$. Thus, the development of a next-generation vaccine is urgently required. The recent proposal of subunit vaccines and DNA vaccines has become a topic for active consideration by researchers for prevention of neosporosis.

Recent research has demonstrated that $N$. caninum microneme proteins are crucial for the initial host cell interaction and invasion process, and during the subsequent phases of infection ${ }^{[9,10]}$. Also, several studies have reported that immunization with microneme proteins, such as NcMIC1, NcMIC2, NcMIC3, NcMIC4, NcMIC6 ${ }^{[11]}$, $\mathrm{NcMIC}^{[12]}$ and NcMIC10, can enhance the humoral immune responses against $N$. caninum. Lovett et al. ${ }^{[13]}$ indicated NcMIC2 may be important for the attachment to and invasion of host cells by $N$. caninum. Cannas et al. ${ }^{[14]}$ reported that recombinant NcMIC3 vaccine confers significant protection against experimentally-induced cerebral neosporosis in mice. In addition, Alaeddine et al. ${ }^{[15]}$ immunized mice with rNcMIC1 proteins and pcDNA$\mathrm{MIC} 1$ and reported that only $\mathrm{rNCMIC} 1$ vaccination appears to reduce cerebral infection in mice challenged with $N$. caninum tachyzoites.

Earlier studies in our laboratory have found that $\mathrm{NcMIC} 3$ and NcMIC 8 are both important adhesion factors in parasite invasion, and $\mathrm{NcMIC} 8$ is present in the parasites in a precursor form and is cleaved into the mature body 
before being transported to the microneme or on secretion. The mature body forms a complex with $\mathrm{NcMIC}^{[12,16]}$. These adhesion factors and complexes may serve functions in the immune response and be potential vaccine candidates. Therefore, we constructed recombinant proteins and DNA vaccines encoding MIC3 and MIC8 antigen of $N$. caninum and evaluated its ability to induce an immune response and partial protective effect in BALB/c mice against neosporosis.

\section{Materials and methods}

\subsection{Ethics statement}

All animal experiments were performed in strict accordance with the recommendations of the Guide for the Care and Use of Laboratory Animals of the Ministry of Science and Technology of China. All experimental procedures were approved by the Institutional Animal Care and Use Committee of China Agricultural University (Certificate of Beijing Laboratory Animal, No: CAU20161210-2).

\subsection{Parasite culture and preparation}

The tachyzoites of $N$. caninum (Nc-1 strain) used in this study were maintained and passaged in African green monkey kidney (Vero) cells cultured in Dulbecco's Modified Eagle's Medium (DMEM) supplemented with L-glutamine and $8 \%$ heat-inactivated fetal bovine serum (FBS) at $37^{\circ} \mathrm{C}$ in a $5 \% \mathrm{CO}_{2}$ environment ${ }^{[16]}$. Parasites were harvested and purified as described previously ${ }^{[11]}$. Tachyzoites were scraped from culture flasks and released by passing the cells through a 27-gauge needle. The parasites were then filtered through a 5 - $\mu \mathrm{m}$ filter (Millipore, Burlington, MA, USA), washed twice with phosphatebuffered saline (PBS) and pelleted at $2000 \times g$ for $10 \mathrm{~min}$.

\subsection{Animals}

Six-week-old female BALB/c mice were purchased from Peking University Health Science Center (Department of Laboratory Animal Science, Beijing, China) and maintained under specific pathogen-free standard conditions.

\subsection{Construction of DNA vaccine plasmid}

The gene sequences of NcMIC3 (NCLIV_010600) and NcMIC8 (NCLIV_062770) were obtained by BLAST in ToxoDB (http://www.toxodb.org/toxo/). Coding sequences of the NcMIC3 gene and NcMIC8 gene were amplified by PCR from $N$. caninum cDNA with synthetic primers.

NcMIC3 (672 bp): 5'- CGGGGTACCGATAAAAGCTACGGAGGTGACT-3' (forward) and 5'-CCGGATATCTTATCGAGCCGTTCCGCATTTGCT-3' (reverse), containing KpnI and EcoRV (NEB, Ipswich, MA, USA) restriction enzyme sites (underlined).

NcMIC8 (453-1380 bp, which has high antigenicity and hydrophilicity, excluding the signal peptide and transmembrane region): 5'-CGGGATCCGGTGCGTATTGCCAGTGCAACGACGG-3' (forward) and 5'-CCGCTCGAGTTCGCAGCTTTTCACTGCTTCTGGC-3' (reverse), containing BamHI and $\mathrm{XhoI}$ restriction enzyme sites (underlined).

The PCR productions of MIC3 and MIC8 gene were digested with the appropriate restriction enzyme $(\mathrm{Kpn} \mathrm{I} /$ EcoRV and BamHI/ XhoI) at $37^{\circ} \mathrm{C}$ overnight and purified from agarose gels. MIC3 and MIC8 gene fragments were inserted into the pcDNA3.1 vector (Novagen, Madison, WI, USA) digested with the same enzyme (KpnI/ EcoRV and BamHI/ XhoI). The plasmid was named pcDNA3.1NcMIC3 and pcDNA3.1-NcMIC8. All recombinant plasmids were transformed into Escherichia coli strain Trans1$\mathrm{T} 1$ and confirmed by restriction analysis. Endotoxin-free plasmid DNA was isolated using a plasmid purification kit (TransGen Biotech, Beijing, China). The concentrations of the purified plasmids were detected by spectrophotometry at 260 and $280 \mathrm{~nm}$. For intramuscular vaccination, the plasmid was formulated in PBS $(\mathrm{pH} 7.5)$ at $1.0 \mathrm{mg} \cdot \mathrm{mL}^{-1}$.

\subsection{In vitro gene expression}

Human embryonic kidney (HEK) 293T cells were cultured at $37^{\circ} \mathrm{C}$ in a $5 \% \mathrm{CO}_{2}$ incubator in DMEM supplemented with $10 \%$ FBS, $100 \mathrm{mg} \cdot \mathrm{mL}^{-1}$ streptomycin and $100 \mathrm{IU} \cdot \mathrm{mL}^{-1}$ penicillin. For the transfection, HEK 293T cells were transferred into six-well plates (Costar, Corning, NY, USA). When the cells reached 80\%-90\% confluence they were transfected with a recombinant eukaryotic expression plasmid (pcDNA3.1-NcMIC3 or pcDNA3.1NcMIC8) using Lipofectamine 2000 (Invitrogen, Thermo Fisher Scientific, Waltham, MA, USA) according to the manufacturer's instructions. The empty plasmid pcDNA3.1 transfected into HEK 293T cells was used as the negative control. The transfected cells were cultured for $6 \mathrm{~h}$ at $37^{\circ} \mathrm{C}$ and $5 \% \mathrm{CO}_{2}$; then the DMEM was replaced. After $48 \mathrm{~h}$ of transfection, the cells were fixed in cold methanol for $20 \mathrm{~min}$. Plasmid expression was detected by indirect immunofluorescence assay (IFA) with rabbit antiNcMIC3 antibody $(1: 50)^{[15]}$ or rabbit anti-NcMIC8 antibody $(1: 50)^{[12]}$ and FITC conjugated goat anti-rabbit immunoglobulin G (IgG) (1:50) (Proteintech, Chicago, IL, USA) as the secondary antibody. After rinsing with PBS three times, coverslips were immediately observed under a fluorescence microscope (Olympus, Tokyo, Japan).

\subsection{Expression and purification of recombinant proteins}

The recombinant plasmids pET28a-NcMIC3 and pET28aNcMIC8 (constructed previously and preserved in our laboratory) were transformed into E. coli BL21 (DE3) for protein expression. $\mathrm{rNcMIC} 3$ and $\mathrm{rNcMIC} 8$ fused to a 
His $_{6}$-tag were expressed and purified using HisTrap FF purification columns (Novagen, Merck KGaA, Darmstadt, Germany) following the manufacturer's protocol. Expression and purification of proteins were assessed by $12 \%$ $(\mathrm{w} / \mathrm{v})$ sodium dodecyl sulfate polyacrylamide gel electrophoresis (SDS-PAGE) and immunoblotting as previously described $^{[16]}$. The concentration of proteins was determined using a BCA protein assay kit (Kangwei, Beijing, China). The purified recombinant proteins were then used for immunization of mice.

\subsection{Vaccination and challenge}

Mice were randomly divided into six groups (10 mice per group). Before immunization, mice were checked serologically for the absence of anti- $N$. caninum immunoglobulins (pre-immune serum) by IFA ${ }^{[17]}$. Each group was vaccinated three times on days 0,14 and 28 as follows. Group 1 and Group 2 were immunized by subcutaneous injections with recombinant proteins $\mathrm{rNcMIC} 3$ and rNcMIC8. The immunization injections were given at $100 \mu \mathrm{g}$ per mouse for the first dose and $50 \mu \mathrm{g}$ per mouse for the second and third doses. Freund's complete adjuvant (Sigma-Aldrich, St. Louis, MI, USA) was added to the first injection, and Freund's incomplete adjuvant was added to the second and third immunization injections. Group 3 and Group 4 were immunized intramuscularly in their hind legs with $100 \mu \mathrm{L}$ of PBS containing $100 \mu \mathrm{g}$ pcDNA3.1NcMIC3 and pcDNA3.1-NcMIC8 for the first dose and $50 \mu \mathrm{g}$ per mouse for the second and third doses. The other two groups of mice were injected with empty vector or with PBS as a control. Blood samples were collected by retro-orbital plexus puncture on days 13, 27 and 55, and the sera were stored at $-20^{\circ} \mathrm{C}$ for serological analysis. On day 42 , all groups were challenged intraperitoneally with $1 \times 10^{6}$ tachyzoites of the Nc-1 strain. All animals were sacrificed by $\mathrm{CO}_{2}$ euthanasia 30 days post-infection.

\subsection{Measurement of the levels of antibodies}

To evaluate the humoral immune response, the sera of mice were collected after each immunization and after challenge to analyze for $N$. caninum specific $\operatorname{IgG}, \operatorname{IgG} 1$ and $\operatorname{IgG} 2$ a by ELISA. Briefly, the ELISA plates were coated with lysate antigen of $N$. caninum $\left(0.5 \mu \mathrm{g}\right.$ per well) at $4^{\circ} \mathrm{C}$ overnight, washed three times with PBST (PBS plus $0.05 \%$ Tween $20, \mathrm{pH} 7.4$ ) and blocked with $3 \% \mathrm{BSA}$ at $37^{\circ} \mathrm{C}$ for $1 \mathrm{~h}$. Serum samples were diluted $1: 50$ in $3 \%$ BSA and incubated for $1 \mathrm{~h}$ at $37^{\circ} \mathrm{C}$. After washing, plates were incubated with horseradish peroxidase conjugated goat anti-mouse $\operatorname{IgG}, \operatorname{IgG} 1$ or IgG2a (1:8000 dilution; Proteintech) at $37^{\circ} \mathrm{C}$ for $1 \mathrm{~h}$. Next, the diluted solution of o-phenylenediamine and $\mathrm{H}_{2} \mathrm{O}_{2}$ were added and incubated for about $20 \mathrm{~min}$ in the dark. The reaction was terminated by $\mathrm{H}_{2} \mathrm{SO}_{4}\left(2 \mathrm{~mol} \cdot \mathrm{L}^{-1}, 50 \mu \mathrm{L}\right)$ and the absorbance value was measured at $450 \mathrm{~nm}$ by a microplate reader (EL680,
BioTek, Winooski, VT, USA). All assays were performed in triplicate.

\subsection{Assessment of serum levels of IL-4 and IFN- $\gamma$}

The serum levels of IFN-gamma (IFN- $\gamma$ ) and interleukin-4 (IL-4) were determined using commercial mouse cytokine/ chemokine kits (Dakewe Biotech, Shenzhen, China). The final immunization sera were analyzed according to the manufacturer's protocol. Cytokine concentrations were determined by referring to the standard curves constructed with known amounts of mouse recombinant IFN- $\gamma$ and IL-4 (provided by the kit manufacturer). All assays were performed in triplicate.

\subsection{Assessment of cerebral parasite burden}

The parasite burden in the brain of $N$. caninum-infected mice was calculated by quantitative real-time $\operatorname{PCR}^{[18,19]}$. Mice (six mice per group) were sacrificed at the end of the experiment, and their brains were removed. DNA of brain tissues in mice was extracted using a DNA extraction kit (Aidlab Biotech, Beijing, China) according to the manufacturer's instructions. PCR, to amplify the Nc5 gene and 28S rRNA, was performed as separate assays as described previously ${ }^{[20]}$. The amplification of the Nc5 gene was used to detect the quantification of $N$. caninum DNA, and the 28S rRNA gene was chosen for the quantification of host DNA. Amplifications were performed with an ABI PRISM $^{\circledR} 7500$ Real-time PCR System, using a SYBR ${ }^{\circledR}$ Premix Ex Taq ${ }^{\mathrm{TM}}$ II Real Time kit (TaKaRa, Dalian, China) with the recommended protocol. All the standards and samples were analyzed in triplicate. The results were analyzed automatically by the 7500 Software (v2.0.5, Applied Biosystems, Foster City, CA, USA) and exported to Microsoft Excel (Microsoft, Albuquerque, NM, USA) to calculate the parasitic load in the brains, which was reported as the number of tachyzoites per $\mu \mathrm{g}$ of host DNA.

\subsection{Statistical analysis}

The statistical analysis was performed using the GraphPad Prism 5 (GraphPad Software, San Diego, CA, USA) software package using Student's $t$-test and ANOVA. Statistical significance was reached when $P<0.05$.

\section{Results}

\subsection{Construction of the recombinant plasmids}

The NcMIC3 (Fig. 1A, lane 1) and NcMIC8 (Fig. 1B, lane 1) genes were amplified from cDNA of $N$. caninum by PCR. The NcMIC3 and NcMIC 8 genes were directionally inserted into pcDNA3.1 to create the pcDNA3.1-NcMIC3 and pcDNA3.1-NcMIC8 recombinant plasmids. To ensure 
the correct insert orientation, pcDNA3.1-NcMIC3 was identified by digestion with $K p n \mathrm{I}$ and EcoRV restriction enzymes, the $672 \mathrm{bp}$ fragment of NcMIC3 gene was excised (Fig. 1A, lane 2), pcDNA3.1-NcMIC8 was identified by digestion with $B a m \mathrm{HI}$ and $\mathrm{XhoI}$ restriction enzyme and the $927 \mathrm{bp}$ fragment of NcMIC8 gene was excised (Fig. 1B, lane 2); the latter fragment was then characterized by restriction endonuclease digestion as well as PCR amplification. The sequencing results verified that the recombinant plasmids pcDNA3.1-NcMIC3 containing NcMIC3 ORF and pcDNA3.1-NcMIC8 containing NcMIC8 ORF were constructed successfully.

\subsection{Expression of the DNA vaccine in HEK 293T cells}

The expression of pcDNA3.1-NcMIC3 and pcDNA3.1NcMIC8 in vitro was evaluated by IFA $48 \mathrm{~h}$ posttransfection (Fig. 1C). Specific green fluorescence was observed in the HEK $293 \mathrm{~T}$ cells transfected with pcDNA3.1-NcMIC3 (Fig. 1C(a)) or pcDNA3.1-NcMIC8 (Fig. 1C(b)), whereas there was no fluorescence observed in the pcDNA3.1-transfected cells (Fig. 1C(c)). These results suggested that the NcMIC3 and NcMIC8 proteins were successfully expressed in mammalian cells.

\subsection{Expression and purification of rNcMIC3 and rNcMIC8}

The two recombinant proteins were expressed as $\mathrm{His}_{6}{ }^{-}$ tagged fusion proteins in E. coli BL21 and purified by $\mathrm{Ni}^{2+}$-affinity chromatography. Purified proteins were observed by SDS-PAGE. Purified rNcMIC3 was $32 \mathrm{kDa}$ (Fig. 2A), and purified rNcMIC8 was $38 \mathrm{kDa}$ (Fig. 2B). The purified proteins were then used to immunize $\mathrm{BALB} / \mathrm{c}$ mice.

\subsection{Clinical symptoms}

Following vaccination, either by subcutaneous injections or intramuscular delivery, mice were inspected daily for the presence of local reactions at the inoculation sites. No such reactions were found during the experiment. This indicated that vaccination had no adverse effects and suggested that
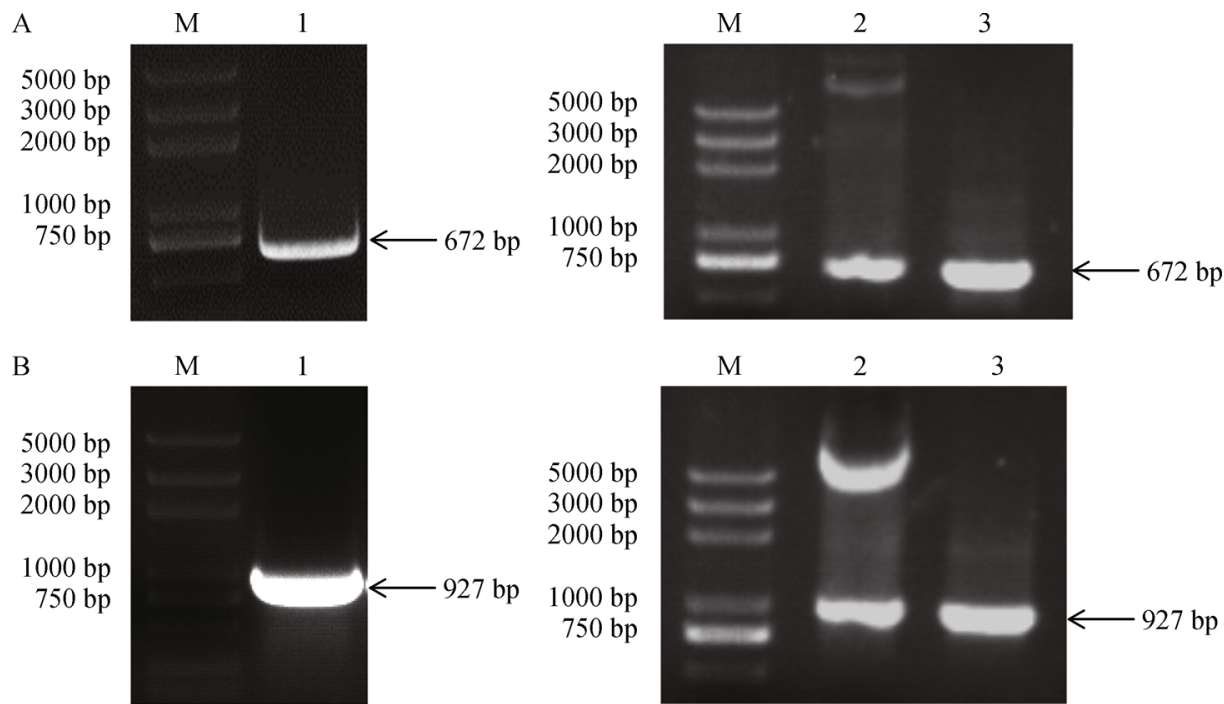

C
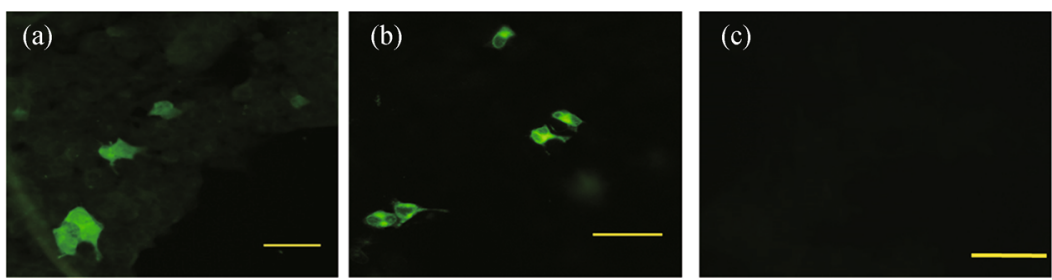

Fig. 1 Construction of eukaryotic expression plasmids and expression in vitro. A: Amplification of NcMIC3 gene (672 bp, lane 1) and identification of the recombinant plasmid pcDNA3.1-NcMIC3 by double digestion (KpnI and EcoRV, lane 2) and PCR (lane 3); B: Amplification of NcMIC8 gene ( $927 \mathrm{bp}$, lane 1) and identification of the recombinant plasmid pcDNA3.1-NcMIC8 by double digestion (BamHI and XhoI, lane 2) and PCR (lane 3). M: Marker. C: Expression of NcMIC3 and NcMIC8 in HEK 293T cells by IFA. (a) HEK 293 T cells transfected with pNcMIC3 react with the anti-NcMIC3 antibody; (b) HEK 293 T cells transfected with pNcMIC8 react with the anti-NcMIC8 antibody; (c) negative control, HEK 293T cells transfected with empty pcDNA3.1 do not react with the anti-NcMIC3 or anti-NcMIC8 antibody. Bar $=20 \mu \mathrm{m}$. 

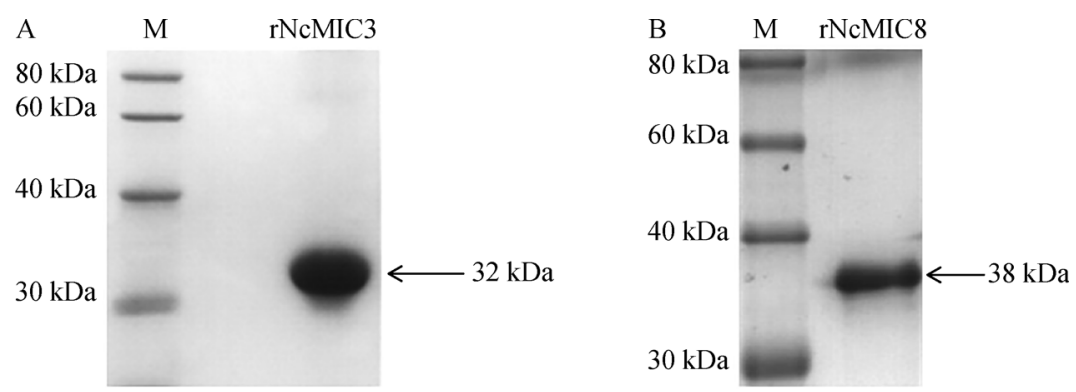

Fig. 2 The purification of NcMIC3 and NcMIC8 recombinant proteins. A: Purified rNcMIC3 (about $32 \mathrm{kDa}$ ) was stained by Coomassie Brilliant Blue after SDS-PAGE; B: Purified rNcMIC8 (about $38 \mathrm{kDa}$ ) was stained by Coomassie Brilliant Blue after SDS-PAGE. M: Protein markers.

all immunization procedures were benign and did not impose stressful conditions that would interfere with the general metabolic activity of the animals. After mice were infected with $N$. caninum tachyzoites, in the control groups we observed clinical signs of neosporosis, such as walking disorders, rounded back, apathy, and paralysis, but few mice acquired such symptoms in the recombinant protein groups and the pcDNA3.1-NcMIC3 group.

\subsection{Humoral immune responses}

Antibody-reactivity against crude $N$. caninum extract was assessed by ELISA. As shown in Fig. 3A, the levels of IgG antibodies in the experimental group gradually increased with successive immunizations. There were significant differences in the sera of mice immunized with rNcMIC3 $(P<0.01)$ and rNcMIC8 $(P<0.05)$ groups compared with the other groups, and high levels of $\mathrm{IgG}$ antibodies were detected in rNcMIC3 and rNcMIC8 groups. There was no significant difference in IgG responses between the DNA vaccine groups $(P>0.05)$. These findings indicate that immunization with $\mathrm{rNcMIC} 3 / \mathrm{rNcMIC} 8$ induced a strong $\mathrm{IgG}$ antibody response in mice.

The levels of IgG subclass (IgG1 and IgG2a) humoral isotype responses against $N$. caninum in immunized BALB/c mice are shown in Fig. 3B. Compared with the control groups, the IgG1 levels in the $\mathrm{rNcMIC} 3$ and rNcMIC8 groups increased significantly $(P<0.01)$ after immunization, while there were no significant differences between the DNA vaccine and control groups. The IgG2a levels in the rNcMIC3 group were clearly higher $(P<0.01)$ than the control and DNA vaccine groups, while the IgG2a levels in the rNcMIC8 group were increased $(P<0.05)$ compared with the control groups (Fig. 3B, IgG2a). The levels of IgG, IgG1, and IgG2a in the rNcMIC3 group were higher than the rNcMIC8 group, although the differences were not significant. These data indicate that the protective efficacy of the rNcMIC3 was better than that of rNcMIC8. The ratio of $\operatorname{IgG} 1 / \operatorname{IgG} 2 \mathrm{a}$ indicated that IgG1 had an obvious advantage over IgG2a in the recombinant proteins groups (rNcMIC3:1.073, $P<0.05$; rNcMIC8: 1.717, $P<0.01$ ) (Fig. 3C). Compared with the other groups, the DNA vaccine groups induced higher levels of IgG2a than IgG1, and the ratio of IgG1/ IgG2a in the pcDNA3.1-NcMIC3 group $(P<0.01)$ was significantly lower than in the other groups. There was no significant difference between mice immunized with PBS or the empty vector. Generally, a predominance of IgG1 over IgG2a was observed in the sera of recombinant proteins groups, which indicated that immunization with rNcMIC3/rNcMIC8 elicited a Th2 type immune response, whereas the DNA vaccine groups elicited a Th1-type immune response.

\subsection{Cytokine expression in sera}

IFN- $\gamma$ and IL-4 serum cytokine levels were determined in sera of all experimental groups. As shown in Table 1, compared with the recombinant proteins and control groups, DNA vaccines generated significantly higher levels of IFN- $\gamma(P<0.05)$, whereas, mice immunized with $\mathrm{rNcMIC} 3(829 \pm 7.3, P<0.01)$ and rNcMIC8 $(715 \pm 7.0, P<0.05)$ produced large amounts of IL-4, and the production was significantly higher than in the other groups. These findings were consistent with the results obtained by the anti- $N$. caninum $\operatorname{IgG}$ isotype, which showed that immunization with DNA vaccines mainly produced a Th1-type immune response, while recombinant proteins elicited a Th2-type immune response.

\subsection{Protection against $N$. caninum in mice}

To test whether the vaccine induced effective protection against $N$. caninum infection, RT-PCR was used to investigate the cerebral parasite burden in vaccinated and non-vaccinated mice (Fig. 4). Quantification of the cerebral parasite burden showed a significant reduction of parasite numbers in $\mathrm{rNcMIC} 3$ and $\mathrm{rNcMIC} 8$ group, followed by the pcDNA3.1-NcMIC3 group. In contrast, the pcDNA3.1-NcMIC8 group induced a higher cerebral 
A

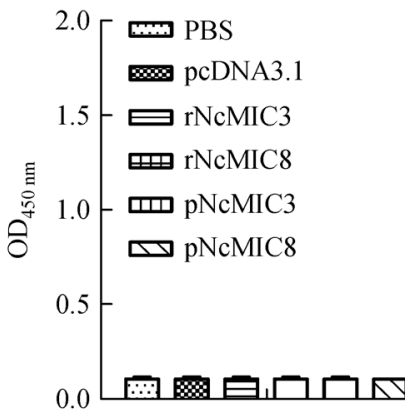

IgG

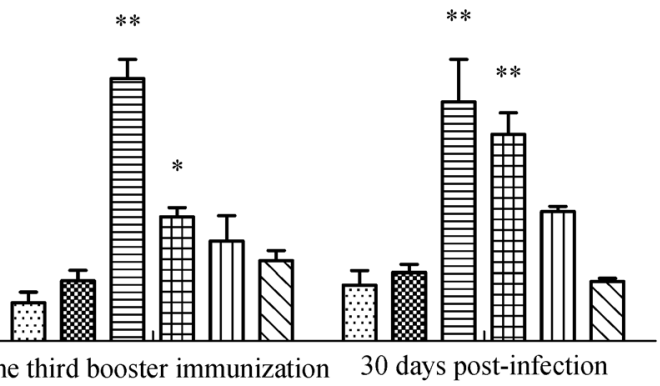

B

IgG1
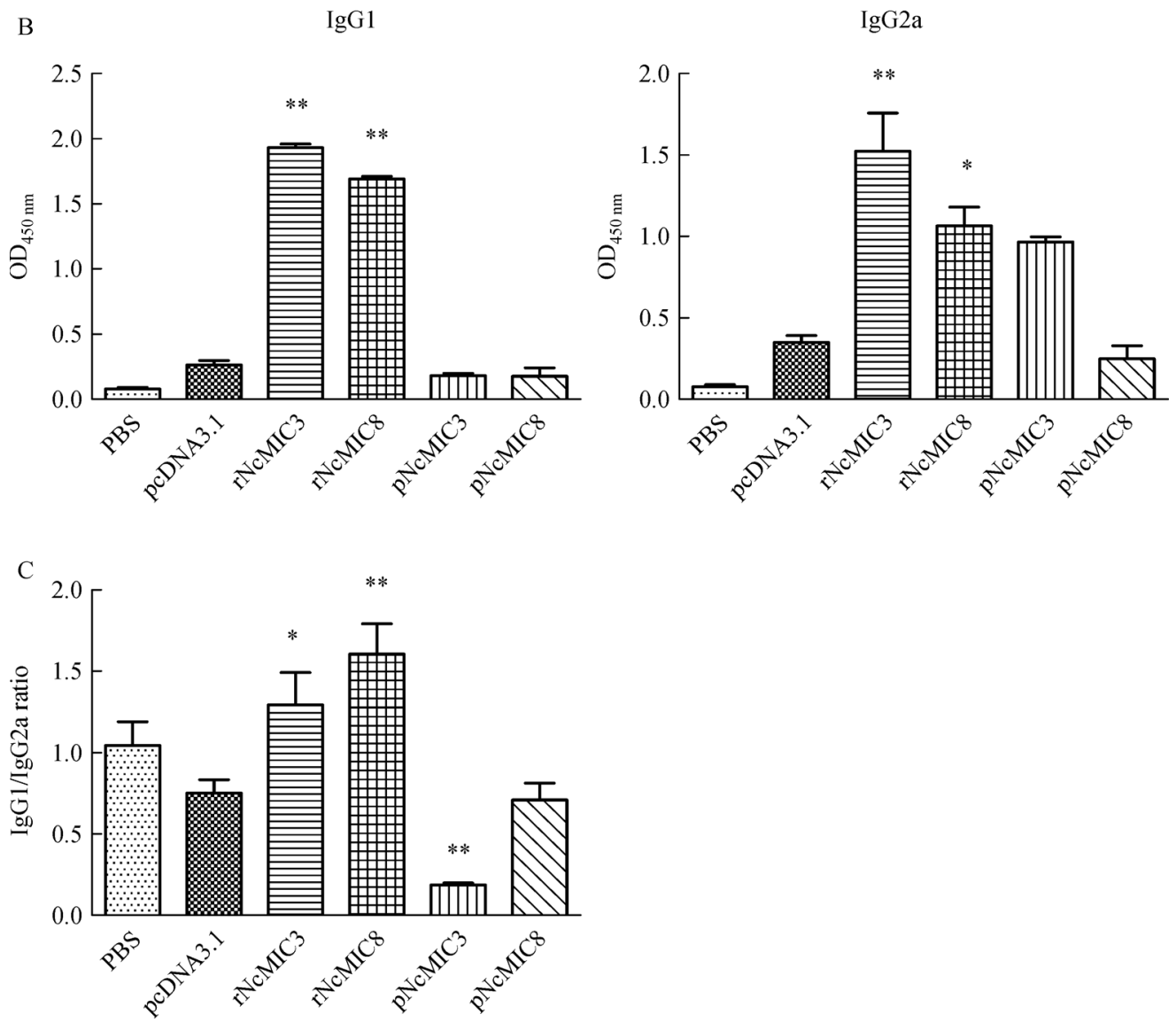

Fig. 3 Neospora caninum-specific antibody levels in the sera of immunized BALB/c mice. A: Levels of IgG antibodies in sera of rNcMIC3, rNcMIC8, pNcMIC3, pNcMIC8, pcDNA3.1, and PBS groups were determined using indirect ELISA. Samples were collected preimmunization, after the third booster immunization and 30 days post-infection $(n=10)$; B: The levels of $\operatorname{IgG} 1$ and $\operatorname{IgG} 2 \mathrm{a}$ subtypes in the sera 28 days after the last immunization were determined by ELISA; C: The IgG1/IgG2a ratio was calculated to determine whether the immunized mice induced a Th1- or a Th2-type immune responses. The results are expressed as the means $\pm \mathrm{SD}$ from three independent experiments. The asterisk designates statistically significant differences $(P<0.05)$ between groups. ${ }^{*} P<0.05$, compared to control groups; ** $P<0.01$, compared to control groups.

parasite burden in mice. These data indicate that rNcMIC3 and $\mathrm{rNcMIC} 8$ vaccines provide partial protection over DNA vaccines by reducing the cerebral infection, and the protective efficacy of the rNcMIC3 vaccine was better than the rNcMIC8 vaccine.

\section{Discussion}

To date, there are no drugs available to treat neosporosis, and current control strategies rely on prevention of infection through management procedures and strict 
Table 1 Cytokines detected in sera from immunized mice

\begin{tabular}{lcc}
\hline Group & $\mathrm{IFN}-\gamma \pm \mathrm{SD} /\left(\mathrm{pg} \cdot \mathrm{mL}^{-1}\right)$ & $\mathrm{IL}-4 \pm \mathrm{SD} /\left(\mathrm{pg} \cdot \mathrm{mL}^{-1}\right)$ \\
\hline rNcMIC3 & $126.56 \pm 2.52$ & $828.84 \pm 7.29^{* *}$ \\
rNcMIC8 & $123.08 \pm 5.30$ & $715.14 \pm 6.98^{*}$ \\
pNcMIC3 & $193.16 \pm 3.73^{*}$ & $525.65 \pm 4.35$ \\
pNcMIC8 & $172.29 \pm 5.57^{*}$ & $696.19 \pm 3.99^{*}$ \\
pcDNA3.1 & $110.16 \pm 7.21$ & $445.12 \pm 4.05$ \\
PBS & $72.38 \pm 3.91$ & $416.70 \pm 8.64$ \\
\hline
\end{tabular}

Note: Sera from mice were obtained one week after the last immunization. Values are shown as the means \pm SD. $* P<0.05$, compared to control groups;

** $P<0.01$, compared to control groups.

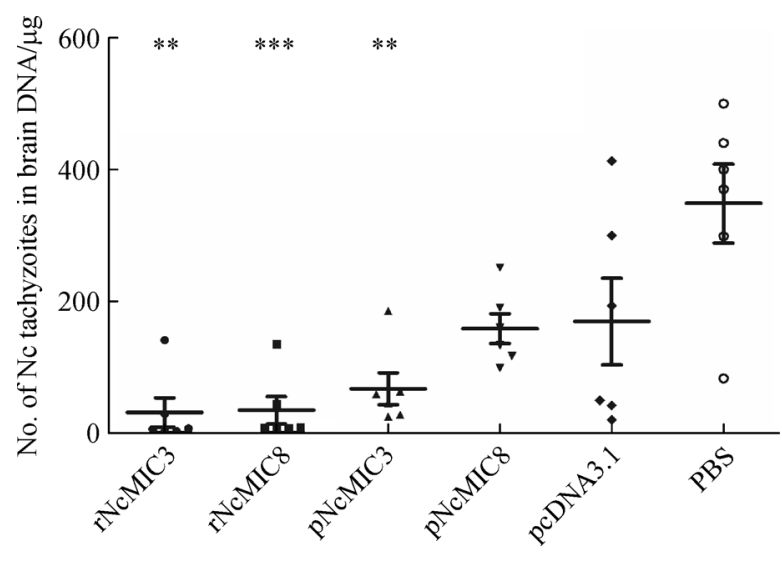

Fig. 4 Neospora caninum burden in brain tissues of mice. The numbers on the $y$-axis correspond to the parasite number per $\mu \mathrm{g}$ of DNA, and each point represents individual animals. The results show that mice immunized with rNcMIC3 or rNcMIC8 and pcDNA3.1-NcMIC3 had reduced brain parasite loads compared to the control groups. In contrast, the pcDNA3.1-NcMIC8 group induced a higher cerebral parasite burden in mice. Values are shown as the means \pm SEM. $P<0.05(*), P<0.01 \quad(* *)$ and

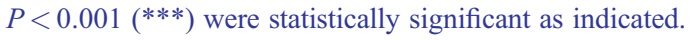

hygiene. Thus, a vaccine able to prevent both horizontal transmission via contaminated food or water and vertical transmission would be a cost-efficient method for the control of neosporosis ${ }^{[21,22]}$. At present, the research on recombinant subunit vaccine of $N$. caninum is mainly focused on the secreted and surface antigens. Cannas et al. ${ }^{[23]}$ reported that NcSAG1 and NcSRS2 effectively prevent the invasion of $N$. caninum, and also effectively inhibit the vertical transmission of $N$. caninum. In addition, rhoptry proteins, microneme proteins and dense granule proteins all participate in the interaction between $N$. caninum and host cells and can also provide immune protection in a mouse model reducing the parasite burden in brain tissues ${ }^{[24]}$. Some $N$. caninum rhoptry and dense granule proteins have been evaluated as vaccine candidates, including NcROP2 ${ }^{[18]}$, NcGRA1, NcGRA2, NcGRA6 and NcGRA7 $7^{[24,25]}$.
Several recent studies have reported that immunization with microneme proteins such as $\mathrm{NcMIC1}, \mathrm{NcMIC} 2$, NcMIC3, NcMIC4 ${ }^{[19]}, \mathrm{NcMIC}^{[11]}, \mathrm{NcMIC} 8^{[12]}$ and NcMIC10 can enhance humoral immune responses against $N$. caninum. Earlier studies in our laboratory found that NcMIC8 forms a complex with NcMIC $3^{[12]}$. In this study, we examined the immunogenic and protective effect of the recombinant proteins and DNA vaccines.

It is informative to evaluate whether the vaccine-induced response is biased toward a Th1 or a Th2 type response. The Th1-type immune response can lead to secretion of a variety of cytokines such as interferon to promote CTL response, which is a common cellular immune response, while the Th2-type immune response, involving secretion of cytokine IL-4, which promotes antibody production, is humoral immune response. The Th1 type produces an IgG2a type antibody, and the Th2 type produces an IgG1 type antibody in mice. Therefore, we used $\operatorname{IgG} 1 / \operatorname{IgG} 2$ a to evaluate which response the vaccine-induced immune response was biased toward. By detecting the IgG antibodies and the cytokine IL-4 and IFN- $\gamma$ in the serum of mice after immunization, we found a high IgG1/IgG2a ratio in sera of recombinant proteins groups. Vaccination with recombinant proteins induced increased IgG1 levels and the mice retained the high IL-4 to IFN- $\gamma$ ratio, whereas, in mice vaccinated with DNA vaccines, IL-4 levels decreased dramatically, and in turn, IFN- $\gamma$ concentrations in the serum increased considerably, and a predominance of IgG2a over IgG1 was observed in the sera of DNA vaccine groups. Various studies have emphasized that Th1-type immune response favor the production of $\operatorname{IgG} 2 \mathrm{a}$, and increased IFN- $\gamma$ production. However, Th2 cytokines, such as IL-4 and IL-10, are associated with the production of $\operatorname{IgG} 1$, the levels of antibody subclasses reflect the in vivo production of cytokines and, thus, the type of immune response ${ }^{[26,27]}$. So, recombinant proteins $\mathrm{rNcMIC} 3$ and $\mathrm{rNcMIC} 8$ induced a Th2-type immune response that could reduce the brain burden in mice challenged with $N$. caninum, while DNA vaccines pcDNA3.1-NcMIC3 and pcDNA3.1-NcMIC8 elicited a Th1-type immune response. 
As $N$. caninum is an intracellular parasite, not only the humoral but also the cellular immune response must be considered as an important mediator of resistance or susceptibility. Resistance to infection, either innate or following immunization, seems to depend on a Th1-type cellular immune response ${ }^{[23]}$. It is possible that a Th1 response is primarily protective against encephalitis, but it cannot effectively inhibit the vertical transmission of $N$. caninum $^{[27]}$. In the late stages of $N$. caninum infection of animals, a Th2 type immune response is more important for inhibiting the proliferation and transmission of the tachyzoites $^{[21]}$. During its life cycle, $N$. caninum secretes many proteins. Various studies have shown that different kinds of proteins can cause different types of immune responses following immunization in mice. For example, NcMAG1, NcBAG1 and NcSAG4 mainly cause Th1 type immune response, and $\mathrm{rNcMIC} 3, \mathrm{NcSRS} 2$ mainly cause Th2 type immune response ${ }^{[14,27,28]}$. However, the type of immune response is not only related to the characteristics of the protein itself, but also depends on other factors, such as the strain of mice, the state of mice at immunization, the method of vaccination and the types of adjuvants used $^{[29,30]}$

The current experimental study of candidate vaccines for $N$. caninum generally involves immunization with candidate antigens followed by challenge with $N$. caninum tachyzoites. The immunization effectiveness of the candidate vaccine is evaluated by weight change, abortion rate, survival time, survival rate and the parasite burden in the brain tissues ${ }^{[31]}$. In this study, we inoculated the tachyzoites at a lower rate of $\left(1 \times 10^{6}\right)$, consequently, the survival rate of mice was $10 \%$ and the difference in weight change was not obvious. Therefore, the parasite burden in the brain was an important factor for the evaluation of the protective effect. The mice immunized with recombinant proteins revealed a lower parasite burden compared with the DNA vaccine and control groups.

It is also important to select effective adjuvants or delivery systems, due to their significant functions in increasing the immunogenicity of antigens via induction of proper immune responses, improving the efficacy and determining the type of immune responses induced by different vaccines ${ }^{[32]}$. Several studies have reported that different combinations of antigens can improve immune protective effects. In our study, we did not evaluate combinations of protein or protein and DNA plasmids, mainly because we wanted to know the protective effect of each protein individually, and protection provided by combinations will be assessed in subsequent experiments.

In general, our study suggests that $\mathrm{rNcMIC} 3$ and rNcMIC8 had the ability to partly protect mice against $N$. caninum and should be considered as vaccine candidates for neosporosis. Whether these two proteins can effectively prevent the vertical transmission of $N$. caninum and whether DNA vaccine can inhibit in the process of $N$. caninum infection are questions for further research.

Acknowledgements Project support was provided by the National Key Research and Development Program of China (2017YFD0501200), the National Key Basic Research Program (973 program) of China (2015CB150300), the National Natural Science Foundation of China (31772730)

Compliance with ethics guidelines Taotao Zhang, Xiao Zhang, Qun Liu, Jianhai $\mathrm{Xu}$, and Jing Liu declare that they have no conflicts of interest or financial conflicts to disclose.

All applicable institutional and national guidelines for the care and use of animals were followed.

\section{References}

1. Dubey J P, Schares G, Ortega-Mora L M. Epidemiology and control of neosporosis and Neospora caninum. Clinical Microbiology Reviews, 2007, 20(2): 323-367

2. Mansilla F C, Capozzo A V. Apicomplexan profilins in vaccine development applied to bovine neosporosis. Experimental Parasitology, 2017, 183: 64-68

3. Pereira L M, de Luca G, Abichabki N L M, Bronzon da Costa C M, Yatsuda A P. Synergic in vitro combinations of artemisinin, pyrimethamine and methylene blue against Neospora caninum. Veterinary Parasitology, 2018, 249: 92-97

4. Ma L, Liu G, Liu J, Li M, Zhang H, Tang D, Liu Q. Neospora caninum ROP16 play an important role in the pathogenicity by phosphorylating host cell STAT3. Veterinary Parasitology, 2017, 243: $135-147$

5. Nishikawa Y. Towards a preventive strategy for neosporosis: challenges and future perspectives for vaccine development against infection with Neospora caninum. Journal of Veterinary Medical Science, 2017, 79(8): 1374-1380

6. Lv Q, Xing S, Gong P, Chang L, Bian Z, Wang L, Zhang X, Li J. A $78 \mathrm{kDa}$ host cell invasion protein of Neospora caninum as a potential vaccine candidate. Experimental Parasitology, 2015, 148: $56-65$

7. Rojo-Montejo S, Collantes-Fernández E, López-Pérez I, RiscoCastillo V, Prenafeta A, Ortega-Mora L M. Evaluation of the protection conferred by a naturally attenuated Neospora caninum isolate against congenital and cerebral neosporosis in mice. Veterinary Research, 2012, 43(1): 62

8. Weston J F, Heuer C, Williamson N B. Efficacy of a Neospora caninum killed tachyzoite vaccine in preventing abortion and vertical transmission in dairy cattle. Preventive Veterinary Medicine, 2012, 103(2-3): 136-144

9. Burleigh B A, Soldati D. Molecular mechanisms of parasite invasion. In: Carruthers V B, Tomley F M, eds. Microneme proteins in Apicomplexans. New York: Landes Bioscience; Springer Science + Business Media, 2008, 47: 33-45

10. Debache K, Alaeddine F, Guionaud C, Monney T, Müller J, Strohbusch M, Leib S L, Grandgirard D, Hemphill A. Vaccination 
with recombinant NcROP2 combined with recombinant NcMIC1 and $\mathrm{NcMIC} 3$ reduces cerebral infection and vertical transmission in mice experimentally infected with Neospora caninum tachyzoites. International Journal for Parasitology, 2009, 39(12): 1373-1384

11. Li W, Liu J, Wang J, Fu Y, Nan H, Liu Q. Identification and characterization of a microneme protein (NcMIC6) in Neospora caninum. Parasitology Research, 2015, 114(8): 2893-2902

12. Wang J, Tang D, Li W, Xu J, Liu Q, Liu J. A new microneme protein of Neospora caninum, NcMIC8 is involved in host cell invasion. Experimental Parasitology, 2017, 175: 21-27

13. Lovett J L, Howe D K, Sibley L D. Molecular characterization of a thrombospondin-related anonymous protein homologue in Neospora caninum. Molecular and Biochemical Parasitology, 2000, 107 (1): $33-43$

14. Cannas A, Naguleswaran A, Müller N, Gottstein B, Hemphill A. Reduced cerebral infection of Neospora caninum-infected mice after vaccination with recombinant microneme protein NcMIC3 and ribi adjuvant. Journal of Parasitology, 2003, 89(1): 44-50

15. Alaeddine F, Keller N, Leepin A, Hemphill A. Reduced infection and protection from clinical signs of cerebral neosporosis in C57BL/ 6 mice vaccinated with recombinant microneme antigen $\mathrm{NcMIC1}$. Journal of Parasitology, 2005, 91(3): 657-665

16. Yang D, Liu J, Hao P, Wang J, Lei T, Shan D, Liu Q. MIC3, a novel cross-protective antigen expressed in Toxoplasma gondii and Neospora caninum. Parasitology Research, 2015, 114(10): 37913799

17. Eperon S, Brönnimann K, Hemphill A, Gottstein B. Susceptibility of B-cell deficient C57BL/6 (microMT) mice to Neospora caninum infection. Parasite Immunology, 1999, 21(5): 225-236

18. Debache K, Guionaud C, Alaeddine F, Mevissen M, Hemphill A. Vaccination of mice with recombinant NcROP2 antigen reduces mortality and cerebral infection in mice infected with Neospora caninum tachyzoites. International Journal for Parasitology, 2008, 38(12): 1455-1463

19. Srinivasan S, Mueller J, Suana A, Hemphill A. Vaccination with microneme protein NcMIC4 increases mortality in mice inoculated with Neospora caninum. Journal of Parasitology, 2007, 93(5): 1046-1055

20. Hao P, Yang N, Cui X, Liu J, Yang D, Liu Q. First isolation of Neospora caninum from blood of a naturally infected adult dairy cow in Beijing, China. Journal of Parasitology, 2014, 100(6): 812816

21. Monney T, Debache K, Grandgirard D, Leib S L, Hemphill A. Vaccination with the recombinant chimeric antigen recNcMIC3-1-R induces a non-protective Th2-type immune response in the pregnant mouse model for $N$. caninum infection. Vaccine, 2012, 30(46): 6588-6594

22. Ybañez R H, Leesombun A, Nishimura M, Matsubara R, Kojima M, Sakakibara H, Nagamune K, Nishikawa Y. In vitro and in vivo effects of the phytohormone inhibitor fluridone against Neospora caninum infection. Parasitology International, 2016, 65(4): 319322

23. Cannas A, Naguleswaran A, Müller N, Eperon S, Gottstein B, Hemphill A. Vaccination of mice against experimental Neospora caninum infection using NcSAG1- and NcSRS2-based recombinant antigens and DNA vaccines. Parasitology, 2003, 126(Pt 4): 303312

24. Liddell S, Parker C, Vinyard B, Jenkins M, Dubey J P. Immunization of mice with plasmid DNA coding for NcGRA7 or NcsHSP33 confers partial protection against vertical transmission of Neospora caninum. Journal of Parasitology, 2003, 89(3): 496-500

25. Álvarez-García G, Pitarch A, Zaballos A, Fernández-García A, Gil C, Gómez-Bautista M, Aguado-Martínez A, Ortega-Mora L M. The NcGRA7 gene encodes the immunodominant $17 \mathrm{kDa}$ antigen of Neospora caninum. Parasitology, 2007, 134(1): 41-50

26. Monney T, Rütti D, Schorer M, Debache K, Grandgirard D, Leib S L, Hemphill A. RecNcMIC3-1-R is a microneme- and rhoptry-based chimeric antigen that protects against acute neosporosis and limits cerebral parasite load in the mouse model for Neospora caninum infection. Vaccine, 2011, 29(40): 6967-6975

27. Uchida M, Nagashima K, Akatsuka Y, Murakami T, Ito A, Imai S, Ike K. Comparative study of protective activities of Neospora caninum bradyzoite antigens, NcBAG1, NcBSR4, NcMAG1, and NcSAG4, in a mouse model of acute parasitic infection. Parasitology Research, 2013, 112(2): 655-663

28. Haldorson G J, Mathison B A, Wenberg K, Conrad P A, Dubey J P, Trees A J, Yamane I, Baszler T V. Immunization with native surface protein NcSRS2 induces a Th2 immune response and reduces congenital Neospora caninum transmission in mice. International Journal for Parasitology, 2005, 35(13): 1407-1415

29. Ramamoorthy S, Sanakkayala N, Vemulapalli R, Duncan R B, Lindsay D S, Schurig G S, Boyle S M, Kasimanickam R, Sriranganathan N. Prevention of lethal experimental infection of C57BL/6 mice by vaccination with Brucella abortus strain RB51 expressing Neospora caninum antigens. International Journal for Parasitology, 2007, 37(13): 1521-1529

30. Rojo-Montejo S, Collantes-Fernández E, Regidor-Cerrillo J, Rodríguez-Bertos A, Prenafeta A, Gomez-Bautista M, OrtegaMora L M. Influence of adjuvant and antigen dose on protection induced by an inactivated whole vaccine against Neospora caninum infection in mice. Veterinary Research, 2011, 175(3-4): 220-229

31. Hemphill A, Debache K, Monney T, Schorer M, Guionaud C, Alaeddine F, Mueller N, Mueller J. Proteins mediating the Neospora caninum-host cell interaction as targets for vaccination. Frontiers in Bioscience, 2013, 5(1): 23-36

32. Ahmadpour E, Sarvi S, Hashemi Soteh M B, Sharif M, Rahimi M T, Valadan R, Tehrani M, Khalilian A, Montazeri M, Daryani A. Evaluation of the immune response in BALB/c mice induced by a novel DNA vaccine expressing GRA14 against Toxoplasma gondii. Parasite Immunology, 2017, 39(4): e12419 